TURIZAM

Volume 16 , Issue 1

1-7 (2012)

\title{
Financial Accountant Versus Managerial Accountant in the Hotel Business System
}

\author{
Ivana Zubac* \\ Received: July 2011 | Accepted: December 2011
}

\begin{abstract}
From the perspective of financial or managerial accountant, subject of interest in this paper is the relationship of financial and managerial accounting in the hotel business. Being necessary functions within the business system of hotel company, their mutual connection as well as their differences are explained. The management of hotel company makes decisions based on accounting information from both parts of accounting. As support to hotel management in decision-making, financial accountant provides financial information about past events, while managerial accountant provides non-financial information oriented toward future. The example above is just one out of many specific tasks, which are performed by accountants of specific part of hotel accounting system. Without their support, the management could not make correct and timely decisions with certainty. The importance of the roles of financial and managerial accountant is reflected through need for a wide knowledge in the field of accounting in specific business conditions of hotel industry.
\end{abstract}

Keywords: financial accountant, managerial accountant, management, decision making, hotel business system.

\section{Introduction}

Accounting as a sub-function of managing function, takes a central place in informing the management in a hotel business system. According to the purpose and nature of information, accounting can be divided into financial and managerial accounting. Financial accounting is intended to provide information of achieved business results, primarily to external users. Accordingly, the information has a general character. The final product of financial accounting are the financial reports, which must be prepared in accordance with generally accepted accounting principles. Managerial accounting has for aim to provide and analyze the information, which are necessary for managing of a hotel company. That's why, the information is detailed and intended for the management of a hotel, for the purposes of planning, control and business decision making. In contrast to external users, to whom the financial reports

\footnotetext{
* Faculty of Tourism and Hotel Management, University of Montenegro, Stari grad 320, 5330 Kotor, Montenegro, e-mail: ivanazu@ac.me, tel. 0038269304366
} 
are the only available source, management has at their disposal the internal sources of information.

Based on the general split between financial and managerial accounting, different functions are performed by accountants in the hotel business. In the reporting process, the cooperation of financial and managerial accountant is necessary, which is further extended to the management of hotel company. Thus, management accountant has a key role in connecting the two sides of the business system within the hotel. For example, financial accounting gives the data to managerial accounting about the inventories and types of costs. Managerial accounting processes the data on appropriate way, periodically preparing data of the inventory effects for financial accounting and managerial information for the hotel management.

Developing over time, the content of the accounting was changing and its structural parts became more complex. Therefore, besides financial and managerial accounting, within the hotel business system can be distinguished cost accounting. It covers the calculation of costs and revenues in order to plan and control them. Analytical data, taken from financial accounting, are processed further in order, to create useful information about future costs, based on the historical costs. From mentioned above, it is concluded that the cost accounting activities can be classified under the managerial accounting. According to contemporary concept, cost accounting is covered by the area of managerial accounting. This theory simplifies and provides an interactive relationship of financial and managerial accounting and, at the same time, a clearly distinguishes their complex and different tasks. The further text of this paper is focused on functioning of a hotel business system with contemporary accounting support.

\section{The Role of Financial and Managerial Accountant in the Hotel Business System}

The function of the financial accountant is required in all business systems in the hotel industry. It refers to the management of (basic and suppleme ntary) business books and preparation of financial reports of the hotel. The function of financial accountant is performed based on legislative framework and in compliance with the International Accounting Standards as obligatory. Historically, as the oldest part of the accounting, financial accounting is a business function that is primarily developed. In the financial accounting, basic accounting categories' data are collected, classified, recorded in chronology and summarized. Therefore, revenues, expenses, assets and liabilities previously recorded in the books, are shown aggregated in the financial reports. While being the main source of data for numerous external users (customers, suppliers and other creditors), financial reporting is also useful to internal users (Weygandt, Keiso, Kimmel, DeFranco, 2008).

However, besides the summary of external information, hotel management requires additional internal information. Managerial accountant is responsible for internal reporting. Position of managerial accountant in the hotel business system has been developed as an upgrade to the position of financial accountant. Besides general knowledge of accounting, managerial accountant is required to know the internal working processes in the specific conditions of the hotel business. Management accountant should have the answer about profitability of introducing new services in the hotel, which and in which amount costs are caused by each individual effect, which department in the hotel achieves the best results and so on. Job of managerial accountant refers to the functions of planning and control. By planning of revenues and costs, controlling of achieved periodic results and comparing of planned and achieved, eventual deviations are observed and assessments made. Managerial 
accountant provides detailed internal information to management of the hotel, which makes the corrections if necessary, and makes decisions about future business events.

How jobs of financial and managerial accountant are connected and yet different, it is easiest to see by confronting their business activities. Different approaches to incorporate the data and prepare the information for their main customers, as well as goals to be achieved by financial and managerial accountant, are reflected in the following (Garrison, Noreen, 1997):

a) Reports prepared by financial accountant are primarily directed toward external users: customers, suppliers and other creditors, investors, lenders, government, public etc. In contrast to that, the reports prepared by managerial accountant are intended for internal users, which primarily refers to the management of a hotel company.

b) Financial accountant records the financial success of a hotel company for a certain period of time and financial position at the end of the period, while managerial accountant reports with purpose of planning, control and decision making.

c) In contrast to the financial accountant who reports to external users about past business events, managerial accountant provides information for decision making in internal operations, as well as feedback for the control and management of responsibility centres in the hotel.

d) The reports of financial accountant have to be based on regulations, either nationally accepted International or National Accounting Standards or generally accepted accounting principles. In contrast to that, the managerial accountant does not have to comply fully with the provisions of International and National Accounting Standards and principles, but primarily follows the standards and specifics in the hotel industry.

e) Financial accountant is required to truthfully and fairly present the financial reports in accordance with the International Accounting Standards, while for the information prepared internally, hotel management decides which information are necessary and how to display them on the most appropriate way.

f) Unlike the financial accountant, to whom the objective and reliable data are the most important, for managerial accountant it is important that current data have the characteristics of flexibility and relevance, in the sense that they are important for decision makers. Financial accountant, in preparing and providing information, emphasizes their consistency and accuracy, while information of managerial accountant may have a subjective character, because they depend on his knowledge and experience.

g) Contrary to the financial accountant who provides mainly value stated information presented in the basic financial reports, financial information by managerial accountant is completed by non-financial information about internal processes, products, customers etc.

h) Financial accountant emphasizes the quantitative values of the effects of business changes that have already occurred, while the managerial accountant is oriented on forecasting of the information, on which is based decision making about the future.

i) It usually occur a considerable delay between the period covered by the report and the date of publication of the report externally. In contrast to that, requirements of managerial accountant are directed towards the timely information.

j) Reports of financial accountant are prepared semi annually and annually, while managerial accountant creates daily, weekly, monthly reports etc., according to the informational requirements of the hotel management and specifics of hotel activities. 
k) Financial accountant accumulates summary information and prepares global reports for the hotel business system as a whole, unlike the managerial accountant who prepares and provides information per responsibility centres and activities, which in the hotel business system represents departments, products, customers, employees, etc.

Emphasized differences in performing the jobs of financial and managerial accountant in the hotel business system are simplified in the table presentation below.

Table 1: The different roles of financial and managerial accountant in the hotel

\begin{tabular}{|c|c|c|}
\hline Criteria of classifying & $\begin{array}{l}\text { Financial accountant } \\
\text { (Financial accounting) }\end{array}$ & $\begin{array}{l}\text { Managerial accountant } \\
\text { (Managerial accounting) }\end{array}$ \\
\hline $\begin{array}{l}\text { a) Users of information (from the } \\
\text { point of further application): }\end{array}$ & $\begin{array}{l}\text { External: customers, suppliers and other } \\
\text { creditors, investors... }\end{array}$ & Internal: management and employees \\
\hline b) Purpose of information: & $\begin{array}{l}\text { Recording of financial success during the } \\
\text { period and financial position at the end } \\
\text { of period }\end{array}$ & Planning, Controlling, Decision-making \\
\hline c) Goal of information: & $\begin{array}{l}\text { Reporting to external users of past busi- } \\
\text { ness events }\end{array}$ & $\begin{array}{l}\text { Providing information for decision } \\
\text { making in internal processesListenRead } \\
\text { phonetically }\end{array}$ \\
\hline $\begin{array}{l}\text { d) Legislative requirements of } \\
\text { information: }\end{array}$ & $\begin{array}{l}\text { Obligatory compliance with the account- } \\
\text { ing principles, standards and regulations } \\
\text { (IAS) }\end{array}$ & $\begin{array}{l}\text { Information is adjusted to requirements } \\
\text { of internal users in making operational } \\
\text { and strategic business decisions }\end{array}$ \\
\hline e) Format of information: & $\begin{array}{l}\text { Truthful and fair view of financial reports } \\
\text { in accordance with IAS }\end{array}$ & $\begin{array}{l}\text { Management decides on the necessary } \\
\text { information and how to display them on } \\
\text { most appropriate way }\end{array}$ \\
\hline f) Nature of information: & $\begin{array}{l}\text { Objective, reliable, consistent, accurate } \\
\text { and prepared according to IAS }\end{array}$ & $\begin{array}{l}\text { May have a subjective character, be } \\
\text { flexible, but must give a relevant as- } \\
\text { sessment of the situation }\end{array}$ \\
\hline g) Type of information: & $\begin{array}{l}\text { Mainly financial, i.e. information in quan- } \\
\text { titative values, presented in the basic } \\
\text { financial reports according to IFRS }\end{array}$ & $\begin{array}{l}\text { Financial and nonfinancial, i.e. quan- } \\
\text { titative information, contained in the } \\
\text { reports for internal users }\end{array}$ \\
\hline h) Period covered: & $\begin{array}{l}\text { Past information, i.e. information of } \\
\text { historical character }\end{array}$ & $\begin{array}{l}\text { Current information and past or future- } \\
\text { oriented information, depending on the } \\
\text { requests of management }\end{array}$ \\
\hline i) Timeliness of information: & $\begin{array}{l}\text { Usually a significant delay between the } \\
\text { period covered by the report and the date } \\
\text { of publication of the report }\end{array}$ & Created with minimal delay \\
\hline j) Frequency of information: & Usually at the annual level & $\begin{array}{l}\text { Frequent as much as it is necessary for } \\
\text { management purposes }\end{array}$ \\
\hline k) Scope of information: & $\begin{array}{l}\text { Aggregated information about the total } \\
\text { hotel business, at the company level } \\
\text { (global) }\end{array}$ & $\begin{array}{l}\text { Detailed, analytical information which } \\
\text { provides making of business decisions } \\
\text { local }\end{array}$ \\
\hline
\end{tabular}

Source: By author, according to ACCA guide, (2006). Financial information for management, Association of Accountants and Auditors of Serbia, Belgrade and Burch, J. (1994). Cost and Management Accounting - A Modern Approach, West Publishing Company, Saint Paul 


\section{The Organization of Accounting Jobs in the Hotel Business System}

The management of hotel company is responsible for coordinating the work of the financial and managerial accountant i.e. external and internal reporting. In case of omission within the accounting or non-harmonized connection between accounting and management, there is a disturbance in the hotel business system, which must be reflected in decrease of business results.

The organization of hotel business system depends on the size and complexity of hotel business, which is determined by workload and staffing. The organization of the smaller hotels is simpler, while in bigger hotels it is more complex (Avelini, I998).

In fact, in the small hotel companies, job of financial and managerial accountant can perform a single person. In addition, the same person can be entrusted to perform the work of analyst. In this case, the accounting service is the only source or a "right hand" to a hotel management. It combines the operations of recording, classification and summary presentation of transactions but also planning, analysis, controlling and internal informing. Business communication, organized through a direct connection accounting-management shows a lot of advantages. However, due to the complex functions performed by one person only, the omissions are possible (Hales, VanHoof, 2005).

In medium hotels it is needed to separately organize activities of financial and managerial accountant. In this case, in the accounting service two persons perform different operations, so it accelerates the process of accounting reporting, either internally or externally. Managerial accountant may perform the duties of analytical services or controlling, in case that department does not exist separately. Depending on the complexity of hotel business, for these jobs, a specialist may be employed occasionally. In some departments functions of planning and control may be organized decentralized (e.g. in food and beverage department, or payment in all places in the hotel, etc.), and if necessary, special analysis of these functions can be performed (Jagels, 2007). In the case of increased workload in the hotel, the function of managerial accountant can be separated from the function of cost accountant. In the organization conceptualized like this, cost accountant should, through the internal calculation of costs that he leads, facilitate and expedite the work of managerial accountant. Cost accountant, in this case, is responsible for: collecting information about the costs and their relation with cost centres, determination of standard and actual costs of departments, processes, activities or products and the accumulation of internal costs calculation. Based on this information, managerial accountants make budgeting of costs and revenues and control the execution of internal processes, while he uses identified deviations for forecasting and management information, further directed to management. Except operations on behalf of managerial accountant, cost accountant is also responsible for the information needed to financial accountant (Schmidgall, Damitio, 2006).

In big hotel companies and hotel chains combined form of organization is used, i.e. centralized - decentralized model. The central office in the main unit of hotel chain incorporates all jobs necessary to management for managing and making strategic decisions. Decentralized, these same jobs are performed at the operational level in hotels (of the chain), for the operational management and decision making. This type of organization requires a variety of different functions that are separate and jobs can be organized as: bookkeeper, financial accountant, managerial accountant, cost accountant, planners, analysts, controllers... These operations are organized by level of responsibility within the hotel unit, as well as on the level of hotel group. Due to the numerous and complex activities separated by hotels and 
levels, it is possible that in a long chain of communication, often comes to its interruption or mismatching (Dopson, Hayes, 2009).

Mentioned theoretical solutions for medium and large organizations in practice are present in most developed hotels throughout the United States, Germany, France etc. In the Montenegrin hotel industry, it is still represented by small hotels with a direct line organization. Also, the bigger hotel complexes are not organized to fit into the theoretical models of separate jobs, but this varies from hotel to hotel. A frequent phenomenon in the most hotel companies is that accountant in the accounting services is performing multiple functions.

The hotel company "Iberostar Bellevue", on the coast of Montenegro, in Bečicii, as part of the Spanish hotel chain "Iberostar Hotels \& Resorts”, serves here as an example of organization of the accounting jobs in the hotel business system. Separate management and ownership functions, within the hotel group, show an advanced way of managing the hotel chain. The central unit, in which top management is located, is in Palma de Mallorca. At the same time, in more than IOO units of hotel chain, across I6 countries in the world, decentralized management model is implemented (www.grupoiberostar.com, 2OIO).

The hotel company "Iberostar Bellevue", categorized with four stars, has 562 commercial accommodation units (rooms and apartments), in which there are total of II74 beds. Workforce engaged in a "peak" season reaches the number of $3 \mathrm{O} 4$ employees, while in the offseason has 50 employees (www.iberostar.com, 2OIO). In the administrative department of such a big hotel company "Iberostar Bellevue" has two services: financial services and controlling. Financial services include accounting activities of bookkeeping, cashier, analysis and preparation of internal reports for management. Controlling includes the planning and control, supervision of accounting services and other departments in the hotel and preparing financial reports for top management and external users. Both services are responsible to financial controller, while controller reports to director of hotel unit and management of hotel group. The accounting functions are not strictly divided and only a few employees together perform common work tasks. In the season or when necessary, the additional number of employees is hired in these service departments of the hotel. A justification of performing a few accounting functions by one person is that the hotel company does not operate whole year, so in that way the costs of employees are reduced to a minimum.

From this example, it is concluded that even in the international hotel chains, the organization does not fully match with the theoretical organizational scheme of accounting operations. Although the characteristics of financial and managerial accountant can be recognized, they are not distributed as separate functions, and they are complementary and overlapping each other. However, modern organizational structure is flexible and adapts to size and other specific conditions in which hotel system operates. Finally, it should not be omitted that, similar to international hotel chains in our area, the best practice solutions are made and developed.

\section{Conclusion}

For performing of contemporary management accounting it is necessary to constantly improve knowledge. World accounting associations and institutions provide professional development and narrow specialization in this field, through organized training. Chartered Institute of Management Accountants (CIMA), as the biggest association of managerial accountants in the United States, after successful completing of the education program, 
issues the certificate of Certified Management Accountant (CMA). It proves that the candidate has acquired a special technical knowledge and that he is competent to perform management accounting. Similar associations exist in Canada, Australia, Japan and the UK (Horngren, Foster, Datar, 2003).

The role of financial or managerial accountant in our country is in its infancy, and the importance of these functions is just being recognized. Unlike financial accountant, who performs his responsibilities in accordance with the International Accounting Standards, the job of managerial accountant is not regulated by standards. As a result, managerial accountant adapts to the specific organizational needs. It is an additional reason to promote the development of managerial accountant function in hospitality. In, so far identified activities of accountant in the hotel companies in Montenegro, several accounting roles are present. To split and foster the cooperation of complex roles of managerial and financial accountant, it is necessary to note the importance of accounting system for the management of a hotel company. As hotel management is not possible without accounting support, by organizing the accounting jobs of financial and managerial accountant in the manner described in this paper, numerous benefits in favour of the hotel business system, are highlighted.

\section{References}

ACCA guide, (2006). Financial information for management, Association of Accountants and Auditors of Serbia, Belgrade

Avelini, I. (1998). Controlling - Performance management, University of Rijeka, Faculty of Hospitality, Opatija

Burch, J. (I994). Cost and Management Accounting - A Modern Approach, West Publishing Company, Saint Paul

Dopson, L., Hayes, D. (2009). Managerial Accounting for the Hospitality Industry, John Wiley and Sons, New Jersey

Garrison, R., Noreen, E. (I997). Managerial Accounting, IRWIN, Chicago

Hales, J., Van Hoof, H. (2005). Accounting and Financial Analysis in the Hospitality Industry - Hospitality Management Essentials, Elsevier Butterworth Heinemann, Oxford

Horngren, C., Foster, G., Datar, S. (2003). Cost Accounting - A Managerial Emphasis, Prentice Hall, Upper Saddle River

Jagels, M. (2007). Hospitality Management Accounting, John Wiley and Sons, New Jersey

Peršić, M., Janković, S. (2006). Managerial accounting of hotel, Croatian Association of Accountants and Financial Experts, Zagreb

Schmidgall, R., Damitio, J. (2006). Hospitality Industry Financial Accounting, Educational Institute, American Hotel and Lodging Educational Association, Lansing

Weygandt, J., Keiso, D., Kimmel, P., DeFranco, A. (2008). Hospitality Financial Accounting, John Wiley and Sons, New Jersey

http://www.grupoiberostar.com/EN/iberostar.html, I8.O2.2OIO

http://www.iberostar.com/iberostar.asp?conccodi=3\&codiconc=IO4, I8.02.2OIO 